\title{
Survey for the Incidence of Wilt Disease Complex of Betelvine
}

\author{
C. V. Nandeesha ${ }^{1 *}$, H. Ravindra ${ }^{2}$ and Nagarajappa Adivappar ${ }^{2}$ \\ ${ }^{1}$ Department of Plant Pathology, College of Agriculture, JAU, Junagadh-362001, India \\ ${ }^{2}$ Department of Plant Pathology, College of Agriculture, UAHS, Shivamogga-577204, India \\ *Corresponding author
}

\section{A B S T R A C T}

\section{Keywords \\ Survey, Sclerotium rolfsii, Meloidogyne incognita, Disease incidence and Root knot index \\ Article Info \\ Accepted: \\ 14 June 2020 \\ Available Online: \\ 10 July 2020}

Rowing survey was conducted during 2016 in major betelvine growing areas of Shivamogga and Davanagere districts of Karnataka state to analyse the incidence of wilt disease complex caused by Sclerotium rolfsii and Meloidogyne incognita. Among the nine taluks surveyed highest incidences of wilt disease and root knot index (RKI) was observed in Harihara taluk (44.37\% and 3.75) of Davanagere district of Karnataka. Whereas, lowest incidences of wilt disease was observed in Bhadravathi taluk $(15.00 \%$ and 2.25) of Shivamogga district.

\section{Introduction}

Betelvine (Piper betle L.) is a perennial climber belongs to family Piperaceae, which is believed to be originated in central and eastern Malaysia. It is valued as both mild stimulant and for its medicinal properties.

The important betelvine growing states in India are Assam, West Bengal, Bihar, Andhra Pradesh, Karnataka, Tamil Nadu, Maharashtra, Madhya Pradesh, Kerala, Uttar Pradesh and Orissa with an estimated area of 53,539 ha (Ray, 2008). In Karnataka, betelvine is grown in Haveri, Davanagere, Tumkur, Ramanagara, Mysore, Dharwad,
Shivamogga, Chikmagalur, North Canara, Belgaum, Bagalkot and Vijayapura districts, in an area of 6988 ha with a production of 1.31 billion leaves with a productivity of 18.86 lakh leaves/ha (Anon., 2011).

Successful cultivation of betel vine suffers from various diseases such as leaf rot and foot rot (Phytophthora spp.), wilt (Pythium, Sclerotium, Rhizoctonia and Fusarium), leaf spot (Colletotrichum capsici) and powdery mildew (Oidium piperis), bacterial leaf spot (Xanthomonas betlicola) and bacterial leaf canker (Bacillus betle) and root knot nematode (Meloidogyne incognita).Among the major diseases, wilt is a disease complex 
caused in association with Phytophthora spp., Rhizoctonia solani, R. bataticola, Fusarium spp., Pythium spp. and Sclerotium rolfsii (Dastur, 1935) and root knot nematode. All these pathogens causes severe crop losses alone or when they are associated with root knot nematode (Medhane and Pawar, 1982). The extent of losses from wilt is up to 100 per cent in betelvine (Saksena, 1977).

\section{Materials and Methods}

Rowing survey was conducted during 2016 in major betelvine growing areas of Shivamogga and Davanagere districts of Karnataka state. In each districts four to five taluks were selected for survey and from each taluks three to four villages were surveyed. In each villages two to three gardens surveyed and infected soil and diseased root samples were collected randomly from five different spots. Later, a composite sample of $200 \mathrm{cc}$ soil and $5 \mathrm{~g}$ roots were put in a polythene bag with proper labeling.

These samples were preserved under refrigerated and the nematode population were assessed by using rhizosphere soil through Combined Baermann's and Cobb's sieving technique (Ayoub, 1977). Wilt incidence was recorded by using the formula given by (Maiti and Sen, 1979).

Per cent disease incidence $=$ Number of plants affected

Total number of plants observed X100

\section{Results and Discussion}

Results from the survey revealed that, wilt complex (S. rolfsii and $M$. incognita), showing yellowing/wilting symptoms, were observed in all surveyed gardens of Shivamogga and Davanagere districts.

The data from Table 1 shows, almost all betelvine gardens were infected with $S$. rolfsii and M. incognita. However, the level of incidence varies from location to location. In Davanagere district, the highest disease incidence was observed in Belludi village $(52.00 \%)$ followed by Banuvalli village (46.00\%) of Harihara taluk. The least disease incidence was recorded in Bhati and Gudekatte (10.00\%) villages.

In Shivamogga district maximum disease incidence was recorded in Mathikai village $(30.00 \%)$ of Hosanagara taluk. There was no disease incidence observed in Siddapura and Sonale villages.

Among different villages of Davanagere district, severe wilt complex was noticed in Banuvalli village with higher nematode population of $709.60 / 200 \mathrm{cc}$ soil and $275 / 5 \mathrm{~g}$ root followed by Belludi (678.00/200cc soil and $254 / 5 \mathrm{~g}$ root) villages of Harihara taluk. The least nematode population of $360.00 / 200 \mathrm{cc}$ soil and $167 / 5 \mathrm{~g}$ root was recorded in Masadi village of Honnali taluk. Similarly, in Shivamogga district, maximum nematode population was recorded in Kunda (682.00/200cc soil and 241/5g root) followed by Mathikai village $(606.00 / 200 \mathrm{cc}$ soil) and the least nematode population was noticed in Sonale village (357.00/200cc soil and 119/ 5g root) of Hosanagara taluk respectively. However, the overall wilt incidence was maximum in Davanagere district compared to Shivamogga district (Table 2).

Taluk wise incidence of wilt complex was maximum in Harihara taluk of Davanagere district with highest RKI of 3.75 and disease incidence of 44.37 per cent and the lowest RKI was recorded in Channagiri (2.75) taluk of Davanagere district. In Shivamogga district, highest RKI was recorded in Teerthahalli taluk (4.00) whereas, the lowest RKI was recorded in Bhadravati taluk (2.25) of Shivamogga district. 
Table.1 Survey for the incidence of wilt complex of betelvine in Shivamogga and Davanagere district during 2016-17

\begin{tabular}{|c|c|c|c|c|c|c|}
\hline $\begin{array}{l}\text { Sl. } \\
\text { No. }\end{array}$ & District & Taluk & Village & $\begin{array}{l}\text { No. of } \\
\text { gardens }\end{array}$ & $\begin{array}{l}\text { \% disease } \\
\text { incidence }\end{array}$ & $\begin{array}{l}\text { Mean \% disease } \\
\text { incidence }\end{array}$ \\
\hline \multirow[t]{20}{*}{1} & \multirow{19}{*}{ Davanagere } & \multirow[t]{4}{*}{ Harihara } & Banuvalli & 5 & 46.00 & \multirow{4}{*}{44.37} \\
\hline & & & Belludi & 5 & 52.00 & \\
\hline & & & GT Katte & 5 & 42.00 & \\
\hline & & & Nanditavare & 4 & 37.50 & \\
\hline & & \multirow[t]{4}{*}{ Harapanahalli } & Gangaralli & 4 & 27.50 & \multirow{4}{*}{27.30} \\
\hline & & & Bikkikatte & 3 & 26.70 & \\
\hline & & & Gundagatti & 4 & 32.50 & \\
\hline & & & Yedehalli & 4 & 22.50 & \\
\hline & & \multirow[t]{4}{*}{ Honnali } & Kunkuva & 3 & 16.70 & \multirow{4}{*}{15.42} \\
\hline & & & Kugunalli & 1 & 20.00 & \\
\hline & & & Gudekatte & 1 & 10.00 & \\
\hline & & & Masadi & 2 & 15.00 & \\
\hline & & \multirow[t]{3}{*}{ Davanagere } & Bhati & 1 & 10.00 & \multirow{3}{*}{21.66} \\
\hline & & & Doddabhati & 2 & 25.00 & \\
\hline & & & Kunduvada & 2 & 30.00 & \\
\hline & & \multirow[t]{4}{*}{ Channagiri } & Nandaghatta & 2 & 25.00 & \multirow{4}{*}{27.50} \\
\hline & & & Erehalli & 1 & 30.00 & \\
\hline & & & Ajjihalli & 2 & 35.00 & \\
\hline & & & Sunagere & 1 & 20.00 & \\
\hline & $\begin{array}{l}\text { District } \\
\text { Mean }\end{array}$ & & & & & 27.25 \\
\hline \multirow{17}{*}{2} & \multirow{16}{*}{ Shivamogga } & \multirow{4}{*}{ Shivamogga } & Abbalagere & 3 & 23.33 & \multirow{4}{*}{18.75} \\
\hline & & & Boodigere & 3 & 16.70 & \\
\hline & & & Aladahalli & 2 & 20.00 & \\
\hline & & & Bannikere & 2 & 15.00 & \\
\hline & & \multirow{4}{*}{ Bhadravathi } & Siddapura & 1 & 00.00 & \multirow{4}{*}{15.00} \\
\hline & & & Mallapura & 3 & 26.70 & \\
\hline & & & Anaveri & 2 & 20.00 & \\
\hline & & & Ittigehalli & 3 & 13.33 & \\
\hline & & \multirow{4}{*}{ Teerthahalli } & Naaluru & 1 & 20.00 & \multirow{4}{*}{18.32} \\
\hline & & & Kunda & 2 & 25.00 & \\
\hline & & & Nanturu & 3 & 13.33 & \\
\hline & & & Honnethalu & 2 & 15.00 & \\
\hline & & \multirow{4}{*}{ Hosanagara } & Mathikai & 2 & 30.00 & \multirow{4}{*}{16.67} \\
\hline & & & Hosur & 1 & 20.00 & \\
\hline & & & Nivane & 3 & 16.70 & \\
\hline & & & Sonale & 1 & 00.00 & \\
\hline & $\begin{array}{l}\text { District } \\
\text { Mean }\end{array}$ & & & & & 17.19 \\
\hline
\end{tabular}


Table.2 Occurrence of root-knot nematode Meloidogyne incognita in betelvine gardens of Shivamogga and Davanagere districts

\begin{tabular}{|c|c|c|c|c|c|c|c|}
\hline Sl. No. & District & Taluk & Village & $\begin{array}{c}\text { No. of } \\
\text { gardens }\end{array}$ & $\begin{array}{l}\text { Nematode } \\
\text { population/ } \\
200 \text { cc soil }\end{array}$ & $\begin{array}{c}\text { Nematode } \\
\text { poulation/ } 5 \mathrm{~g} \\
\text { root }\end{array}$ & $\begin{array}{l}\text { Root knot } \\
\text { indices }\end{array}$ \\
\hline \multirow[t]{20}{*}{1} & \multirow[t]{19}{*}{ Davanagere } & \multirow[t]{4}{*}{ Harihara } & Banuvalli & 5 & 709.60 & 275.40 & \multirow[t]{4}{*}{3.75} \\
\hline & & & Belludi & 5 & 678.00 & 254.60 & \\
\hline & & & GT Katte & 5 & 647.20 & 239.00 & \\
\hline & & & Nanditavare & 4 & 574.50 & 227.00 & \\
\hline & & \multirow[t]{4}{*}{ Harapanahalli } & Gangaralli & 4 & 564.50 & 196.60 & \multirow[t]{4}{*}{3.00} \\
\hline & & & Bikkikatte & 3 & 574.67 & 193.20 & \\
\hline & & & Gundagatti & 4 & 592.50 & 243.40 & \\
\hline & & & Yedehalli & 4 & 530.50 & 210.60 & \\
\hline & & \multirow[t]{4}{*}{ Honnali } & Kunkuva & 3 & 511.33 & 198.80 & \multirow[t]{4}{*}{3.50} \\
\hline & & & Kugunalli & 1 & 416.00 & 171.20 & \\
\hline & & & Gudekatte & 1 & 374.00 & 163.40 & \\
\hline & & & Masadi & 2 & 360.00 & 167.20 & \\
\hline & & \multirow[t]{3}{*}{ Davanagere } & Bhati & 1 & 396.00 & 175.80 & \multirow[t]{3}{*}{3.33} \\
\hline & & & Doddabhati & 2 & 450.00 & 180.80 & \\
\hline & & & Kunduvada & 2 & 425.00 & 168.80 & \\
\hline & & \multirow[t]{4}{*}{ Channagiri } & Nandaghatta & 2 & 426.00 & 160.40 & \multirow[t]{4}{*}{2.75} \\
\hline & & & Erehalli & 1 & 504.00 & 170.60 & \\
\hline & & & Ajjihalli & 2 & 582.00 & 179.00 & \\
\hline & & & Sunagere & 1 & 430.00 & 156.40 & \\
\hline & $\begin{array}{l}\text { District } \\
\text { Mean }\end{array}$ & & & & 508.60 & 195.40 & 3.27 \\
\hline \multirow{16}{*}{2} & \multirow{16}{*}{ Shivamogga } & \multirow{4}{*}{ Shivamogga } & Abbalagere & 3 & 549.67 & 162.60 & \multirow[t]{4}{*}{2.50} \\
\hline & & & Boodigere & 3 & 503.33 & 151.80 & \\
\hline & & & Aladahalli & 2 & 460.00 & 144.80 & \\
\hline & & & Bannikere & 2 & 435.00 & 142.80 & \\
\hline & & \multirow{4}{*}{ Bhadravathi } & Siddapura & 1 & 428.00 & 137.40 & \multirow[t]{4}{*}{2.25} \\
\hline & & & Mallapura & 3 & 522.00 & 145.60 & \\
\hline & & & Anaveri & 2 & 486.00 & 125.80 & \\
\hline & & & Ittigehalli & 3 & 463.33 & 135.80 & \\
\hline & & \multirow{4}{*}{ Teerthahalli } & Naaluru & 1 & 514.00 & 170.80 & \multirow[t]{4}{*}{4.00} \\
\hline & & & Kunda & 2 & 682.00 & 241.00 & \\
\hline & & & Nanturu & 3 & 496.00 & 169.40 & \\
\hline & & & Honnethalu & 2 & 467.00 & 157.20 & \\
\hline & & \multirow{4}{*}{ Hosanagara } & Mathikai & 2 & 606.00 & 222.80 & \multirow{4}{*}{3.50} \\
\hline & & & Hosur & 1 & 484.00 & 145.20 & \\
\hline & & & Nivane & 3 & 595.33 & 163.60 & \\
\hline & & & Sonale & 1 & 357.00 & 118.80 & \\
\hline & $\begin{array}{l}\text { District } \\
\text { Mean }\end{array}$ & & & & 503.25 & 158.75 & 3.06 \\
\hline
\end{tabular}


Taluk wise maximum nematode population and RKI was noticed in Harihara taluk of 652/200cc soil, 3.75 RKI followed by Harapanahalli taluk (565.54/200cc soil) respectively. The least nematode population (415.33/200cc soil) and least RKI of 2.25 recorded in Honnali and Bhadravathi taluk respectively.

The present findings are in confirmity with Parameshwari (2003), who recorded maximum wilt disease incidence in Haveri district (50.63 per cent). The present survey also indicated the association of Meloidogyne and $S$. rolfsii recorded the maximum wilt incidence. These results are also in confirmation with the findings of the survey conducted by AICRP (Betelvine) in Karnataka and Bihar (Anon., 1984 and 2015).

In conclusion roving survey was conducted during 2016 in Davanagere and Shivamogga districts. The maximum wilt incidence was recorded in Davanagere compared to Shivamogga district. Maximum disease incidence of 44.37 per cent and nematode population of $652 / 200 \mathrm{cc}$ soil with $3.75 \mathrm{RKI}$ was recorded in Harihara taluk and the least disease incidence $(15.00$ per cent $)$ and nematode population (474.83/200ccsoil) was recorded in Bhadravathi taluk. The extent of disease incidence varied from location to location due the prevailance of favourable environmental conditions and susceptible cultivar.

\section{References}

Anonymous, 1984, Annual report for 1983-84.
All India Coordinated Research Project on Betelvine, Indian Institute of Horticultural Research, Bangalore, pp. 47-48.

Anonymous, 2011, Horticultural statistics of Karnataka State, Department of Horticulture.

Anonymous, 2015, Annual report for 2014-15. All India Coordinated Research Project on Betelvine, Indian Institute of Horticultural Research, Bangalore, pp. 153-155.

Ayoub, S. M., 1977. Plant Nematology, an agricultural training aid. State of California, Dept. of Food and Agriculture. pp. 157.

Chopra, R. N., Nayar, S. L. and Chopra, I. C., 1956, Glossary of Indian Medicinal Plants, CSIR, New Delhi, pp. 194.

Dastur, J. F., 1935, Diseases of pan (Piper betle L.) in central provinces. Proc. Indian Acad. Sci. 1 (11): 778-815.

Guha, P., 2006, Betel leaf the neglected green gold of India. J. Hum. Ecol., 19(2):87-93.

Maiti, S. and Sen, C., 1979, Fungal diseases of betelvine, PANS, 25:150-157.

Medhane, N. J. and Pawar, A. B., 1982, Proc. First Natl. Workshop on Betelvine: 10911.

Parameshwari, B., 2003, Studies on wilt complex of betelvine (Piper betle Linn.), M.Sc. Thesis, Univ. Agril. Sci., Dharwad.

Ray, D. P., 2008, Keynote Address, National Seminar on Piperaceae, 21-22 November 2008, IISR, Calicut. pp. 26.

Saksena, S. B., 1977, Phytophthora parasitica the secourge of 'pan' (Piper betle L.). Indian Phytopath., 30:1-16.

\section{How to cite this article:}

Nandeesha, C. V., H. Ravindra and Nagarajappa Adivappar. 2020. Survey for the Incidence of Wilt Disease Complex of Betelvine. Int.J.Curr.Microbiol.App.Sci. 9(07): 1557-1561. doi: https://doi.org/10.20546/ijcmas.2020.907.180 